Барибіна Яніна, кандидат економічних наук, доцент, ВНЗ Укоопспілки «Полтавський університет економіки і торгівлі», кафедра менеджменту, м. Полтава; ORCID ID 0000-0001-8139-9081, e-mail: barybinaya@ukr.net

Гайденко Євгенія, аспірантка,

ВНЗ Укоопспілки «Полтавський університет економіки і торгівлі», м. Полтава; ORCID ID 0000-0002-1052-0646, e-mail: Ievgga@gmail.com

https://doi.org/10.29038/2411-4014-2020-02-43-53

\title{
ВПЛИВ ФАКТОРІВ НА КОНКУРЕНТОСПРОМОЖНІСТЬ РИНКУ ТУРИСТИЧНИХ ПОСЛУГ В УКРАЇНІ
}

В статті висвітлюється значення екологічного туризму для розвитку галузі та сільських територій. Проаналізовано вплив факторів на конкурентоспроможність галузі через показники Індексу конкурентоспроможності туризму та подорожей, що дозволило визначити найбільш суттєві 3 них, що потребують уваги керівників на макро-, мезо-, та мікро рівнях. Проведено оцінку туристичних потоків України, яка $\epsilon$ основою для обгрунтування рішень, у пошуках причин низького рівня туристичної привабливості окремих видів туризму. Виокремлено групу факторів на інституційному рівні, що дозволило запропонувати напрями вдосконалення державної політики для підтримки галузі та розвитку окремих туристичних дестинацій. Підтверджена та обгрунтована необхідність перегляду діяльності сільських садиб та роль в процесі контролю якості надаваних послуг саморегулівними організаціями.

Ключові слова: туризм, конкурентоспроможність, туристична дестинація, екологічний туризм.

Барыбина Янина, кандидат экономических наук, доцент, ВУЗ Укоопсоюза «Полтавский университет экономики и торговли», кафедра менеджмента, г. Полтава

Гайденко Евгения, аспирантка,

ВУЗ Укоопсоюза «Полтавский университет экономики и торговли», г. Полтава

\section{ВЛИЯНИЕ ФАКТОРОВ ВЛИЯНИЯ НА КОНКУРЕНТОПОМОБНОСТЬ РЫНКА ТУРИСТИЧЕСКИХ УСЛУГ В УКРАИНЕ}

В статье рассмотрено значение экологического туризма для развития отрасли и сельских территорий. Проведено анализ влияния факторов на конкурентоспособность отрасли через показатели Индекса конкурентоспособности туризма и путешествий, что позволило выделить наиболее значимые среди них и те, что требуют особого внимания со стороны менеджеров на макро-, мезо-, микроуровнях. Проведено оценку туристических потоков Украины, которая является основой для принятия решений в поисках причин низкого уровня конкурентоспособности отдельных видов туризма.

Выделено отдельную группу факторов на институционном уровне, что способствовало разработке предложений пути улучшения государственной политики для поддержания отрасли ы развития отдельных туристических дестинаций. Обоснована необходимость пересмотра деятельности сельских усадеб и роль в процессе их качества саморегулирующим организациям.

Ключовые слова: туризм, конкурентоспособность, туристическая дестинация, экологический туризм. 


\title{
Barybina Yanina, \\ PhD in Economics, \\ Associate Professor, \\ Poltava University of Economics and Trade, Department of Management, \\ Poltava
}

\author{
Gaydenko Evgeniya, \\ Postgraduate Student, \\ Poltava University of Economics and Trade, \\ Poltava
}

\section{THE INFLUENCE OF FACTORS ON THE COMPETITIVENESS OF THE MARKET OF TOURIST SERVICES IN UKRAINE}

The deep crisis due to the spread of the COVID-19 pandemic has become the most tangible for the tourism industry worldwide. The closure of borders in most countries has affected the review of opportunities for domestic tourism. Therefore, this period should be used for deep scientific research of the reasons for the low level of competitiveness of Ukrainian tourism and to develop directions, strategies and tactics to improve the competitive status of Ukrainian tourism in the world.

The aim of the study is to analyze the favorable and critical indicators of competitiveness assessment in tourism in Ukraine and to determine the factors influencing the development of tourist destinations through the promotion of active eco-tourism. The task of the article is to offer practical directions for improving the industry at the institutional and local level in order to increase the competitiveness of destinations and their development through the creation of products of active ecological tourism.

The importance of ecological tourism for the development of the industry and rural areas is substantiated. The influence of factors on the competitiveness of the industry is analyzed through the indicators of the Tourism and Travel Competitiveness Index, which allowed to identify the most significant of them that need the attention of managers at the macro, meso and micro levels. An assessment of tourist flows in Ukraine, which is the basis for justifying decisions, in search of reasons for the low level of tourist attractiveness of certain types of tourism.

A group of factors at the institutional level is singled out and directions for improving state policy to support the industry and development of individual tourist destinations are proposed, namely: the need to review the activities of rural estates and the role of self-regulatory organizations in quality control of provided services; creation of economic incentives for domestic and inbound tourism operators; creation of a trust fund for the use of tourist tax; application of sanctions to business entities that violate the conditions of activity; introduction of modern information and communication technologies at the national and regional levels; development and implementation of an effective communication strategy; development of state targeted programs to promote a healthy ecological lifestyle through incentives for active ecological tourism, which will ultimately contribute to the revival of the industry after the crisis.

Keywords: competitive environment, the market of tourist services, tourist company.

Постановка проблеми та її зазначення. Глибока криза через поширення пандемії COVID-19 найбільш відчутною стала для туристичної галузі у всьому світі. Закриття кордонів у більшості країн позначились на перегляді можливостей для розвитку внутрішнього туризму. Тому даний період необхідно використати для наукового глибинного пошуку причин низького рівня конкурентоспроможності українського туризму та випрацювати напрями, стратегії та тактики із підвищення конкурентного статусу українського туризму в світі.

За прогнозами експертів галузі, як нарівні Всесвітньої туристичної організації так і серед вітчизняних фахівців ринку, запити споживачів туристичного продукту докорінно зміняться у майбутньому, коли стане відчутний попит на екологічний туризм, який пересічний громадянин називає «виїздом на природу». Аби конкурувати за споживача у цьому сегменті ринку, необхідно створити конкурентний туристичний продукт на рівні окремих суб'єктів господарювання так і на рівні дестинацій. Проте, є низка факторів, які цьому процесу не сприяють, а навпаки гальмують. Тож, у всьому світі особливе значення набуває наукове вивчення закономірностей розвитку конкуренції в туризмі та розробка науково-методологічних основ формування конкурентоспроможності ринку туристичних послуг України. 
Аналіз останніх досліджень i публікацій. Проблеми дослідження конкуренції та конкурентоспроможності вивчалися в працях багатьох вчених, зокрема у працях Г. Азоєва, М. Долішнього, О. Кузьміна, Й. Петровича, А. Татаркіна, Р. Фатхутдінова, Л. Чайнікової, $\quad$ Н. Чухрай, Л. Шеховцевої та інших. Методичні аспекти дослідження конкурентоспроможності суб'єктів туристичної діяльності висвітлюють у своїх працях такі вчені: О. Азарян, Л. Балабанова, І. Бочан, О. Виноградова, С. Гаврилюк, А. Дурович, Ф. Поклонський, Полюга, О. Сидорова, Т. Ткаченко, Н. Цопа, Л. Шульгіна.

Разом $з$ тим, не достатньо дослідженими залишаються особливості та специфіка конкуренції в сфері туристичної індустрії на різних рівнях, а також теоретичні та методологічні проблеми формування та забезпечення конкуренції, конкурентного середовища та конкурентоспроможності українського туризму.

Мета і завдання статті. Метою дослідження с проаналізувати сприятливі та критичні показники оцінки конкурентоспроможності в туризмі України та визначити фактори впливу на розвиток туристичних дестинацій через стимулювання активного екологічного туризму. Завданням статті є запропонувати практичні напрями вдосконалення галузі на інституційному та локальному рівні 3 метою підвищення конкурентоспроможності дестинацій та їх розвиток через створення продуктів активного екологічного туризму.

Викладення основного матеріалу обгрунтування отриманих результатів дослідження.

Конкурентоспроможність в туризмі являє собою складне багаторівневе поняття. Для того, щоб туристична індустрія була конкурентоспроможною в дестинації, необхідно, щоб були конкурентоспроможними не тільки окремі підприємства туристичної індустрії, а й рівень розвитку туристичної індустрії був збалансований. Це означає, що на мікро-, мезо- і макрорівні туристичної індустрії повинен проявлятися синергетичний ефект, тобто повинні формуватися нові системні властивості туріндустрії. Зокрема, для туризму синергетичний ефект проявляється у формуванні турпродуктів, які створюються спільно декількома підприємствами туріндустріi, наприклад, туроператором, авіакомпанією і готелем. Якщо в дестинації існують привабливі туристичні ресурси i $\epsilon$ необхідні місця розміщення, але немає якісних засобів доставки туристів, немає доріг, то така дестинація буде неконкурентоспроможною і неможливо буде забезпечити достатній туристський потік [1].

Національна туристична організація України оголосила 2020 рік Роком розвитку туризмув регіонах та сільських місцевостях,який включає як екотуризм, так і відвідування різних місцевостей, громад. Одним словом, сільський туризм охоплює все, що стосується автентичності, традицій, культури та природи у сільській місцевості [2].

За словами Президента Національної туристичної організації України Івана Ліптуги «Мабуть, найбільша потреба сектору - це підготовка мешканців села до вдосконалення своїх сервісних навичок та розвитку людського капіталу, який забезпечить сталий та збалансований розвиток сільського туризму. Крім того, здоровий розвиток сільського туризму вимагає встановлення та впровадження міжнародних стандартів, об'єднаних у комплексну систему якості дестинацій, яка функціонально відповідає сучасним потребам ринку і ефективно підвищує якість обслуговування та управління».

До сільського туризму відноситься організація відпочинку у сільській місцевості. Він тісно пов'язаний з екологічним (зеленим), екскурсійним, активним та іншими видами туризму. Тi, хто відпочивають на селі, доволі часто цікавляться традицією, культурою, особливостями місцевого побуту, пам’ятками історії та природними об'єктами у даній місцевості.

Розвиток сільського (зеленого) туризму в Україні охоплює широке коло туристичнорекреаційної діяльності, а саме:

відпочинок у туристичних та курортних центрах, розташованих у селищах та містечках (зелений туризм), стаціонарний відпочинок у сільській місцевості (сільський туризм), відпочинок у сільських приватних господарствах (агротуризм), а також поєднання відпочинку із заняттям екологічним сільським господарством (екологічний туризм) всебічно сприяють розвиткові даного виду туристичної та рекреаційної діяльності.

Ці види туризму мають наметі відпочинок у сільській екологічно чистій місцевості й максимальне наближення до природи без заподіяння шкоди екосистемі, що визначає екологічну 
орієнтацію визначених видів туризму та використання матеріально-технічної бази і туристичних ресурсів сільських територій.

До того ж розвиток сільського туризму може вирішити декілька задач, таких як:

мінімізація міграції з сільських територій до міст;

забезпечення можливості працевлаштування сільської молоді, етнічних меншин, жінок та маргіналізованих груп;

зменшення бідності;

збереження культурної спадщини.

Незважаючи на те, що, крім розвитку сільського туризму, існують інші пріоритети, всі країни світу визнають його потенціал як засіб диверсифікації своїх продуктів у секторі туризму та індустрії гостинності.

Для розвитку конкуренції в індустрії туризму в Україні, ще не створено всі необхідні умови. Причинами цього є такі аспекти, як:

недостатній рівень фінансування і підтримка з боку держави;

недосконалість правового регулювання відносин між споживачем та туристичними установами; недосконалість законодавчої бази, що стосується розвитку туристичної індустрії;

недостатня кадрова забезпеченість туристичної галузі;

невідповідність діючої системи управління туризмом з інтересами туристичних установ;

відхилення від економічних реформ (податкова політика, оренда, приватизація, система санації тощо) [3].

Зазначені причини є характерними і для активного, екологічного чи зеленого туризму, який має і свої особливості розвитку, позатим, залишається під впливом факторів, що впливають на конкурентоспроможність туристичного ринку на рівні країни.

Якщо подивитись на статистику подорожей у 2019 році за метою подорожі, то маємо наступну картину[4]:

- 3 культурно-пізнавальною метою - 1731,1 тис. осіб;

- службовою - 110,1 тис. осіб;

- лікувально-оздоровчою - 17,2 тис. осіб;

- круїзний туризм - 11,0 тис. осіб;

- міський туризм - 10,7 тис. осіб;

- гірський курорт - 8,9 тис. осіб;

- пригодницький - 6,5 тис. осіб;

- екологічний $-4,4$ тис. осіб;

- інші - 1476,15 тис. осіб.

На даний час громадяни України віддають перевагу закордонним подорожам, які перевищують спектр послуг, що надаються туристичними організаціями України, за своєю якістю та ціновою політикою, про це свідчить статистика в 'їзного до виїзного туризму (Рис.1).

Упродовж 2019 року Україну відвідало 13,6 млн туристів, що на 4,6\% менше, ніж у 2018 році (дані Адміністрації Держприкордонслужби) [4,5].

Територіальні негаразди в країні у 2014 - 2015 роках негативно вплинули на в’їзний туристичний потік до України, що скоротився майже вдвічі. Але вже з 2016 року спостерігалося поліпшення, яке відобразилося у поступовому зростанні в'їзного туристичного потоку до України.

Наразі існує велика кількість міжнародних рейтингів та оцінок рівня розвитку країн світу. Дослідження, що здійснюються авторитетними організаціями, аналізують найцікавіші сфери життєдіяльності суспільства в країнах світу, а отримані результати застосовуються для кореляції соціально-економічних, політичних, культурних аспектів різних країн серед низки досліджуваних.

За міжнародними рейтингами Україна оцінена так:

$\checkmark$ 85-е місце у рейтингу конкурентоспроможності;

$\checkmark$ 78-е місце у рейтингу туристичної привабливості;

$\checkmark$ 57-е місце у рейтингу за розвитком інфраструктури (73-е місце за розвитком туристичної інфраструктури);

$\checkmark$ 107-е місце у рейтингу найбезпечніших країн для туризму;

$\checkmark$ 62-е місце у рейтингу країн з найкращою якістю життя; 
20-е місце у рейтингу небезпечних країн для жінок, які подорожують.

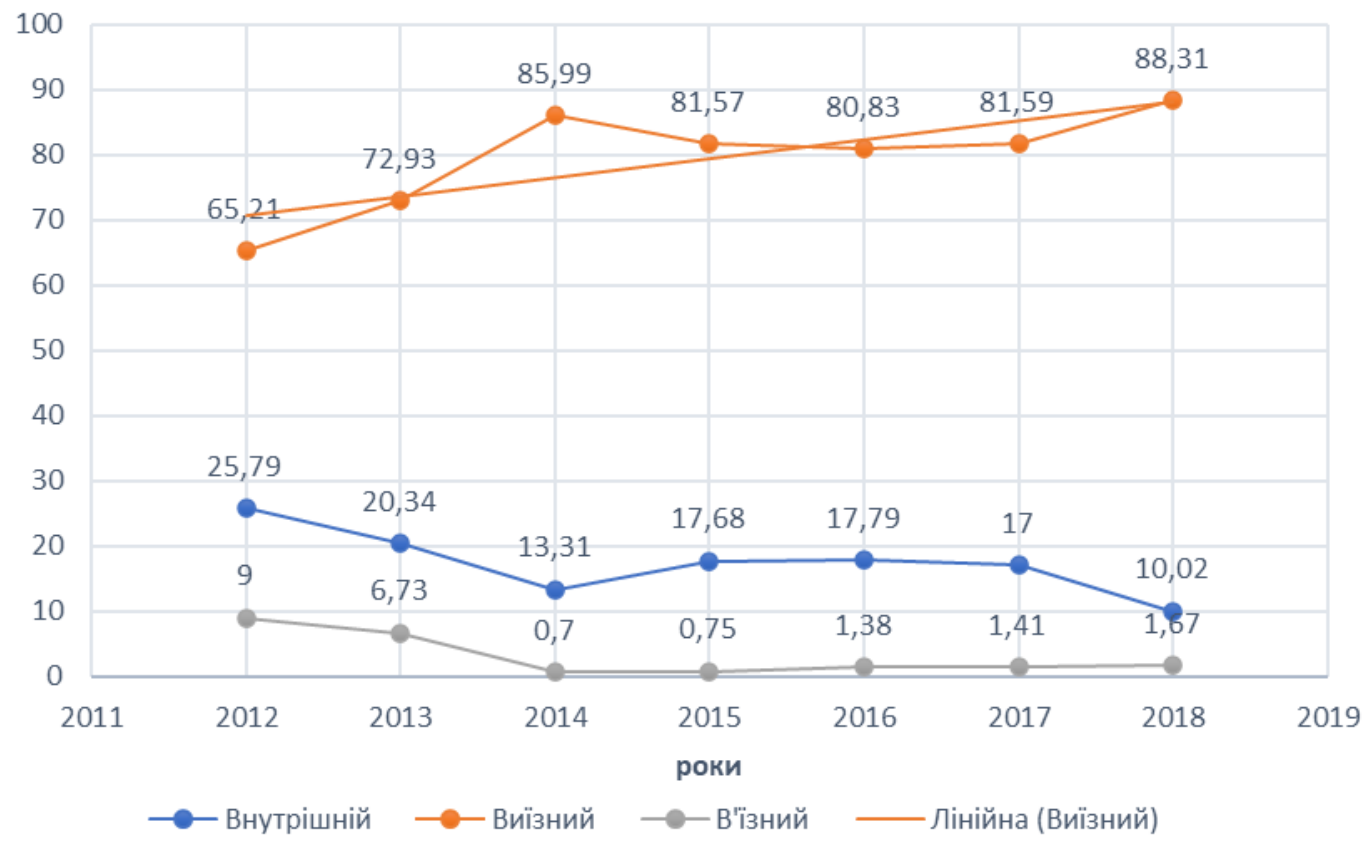

Рис. 1. Частка внутрішнього, виїзного та в'їзного туризму в організованому туризмі , \% Джерело: авторські розрахунки за даними Державної прикордонної служби України [4]

Україна втратила свої позиції у топ-10 найнебезпечніших місць для подорожей у світі.
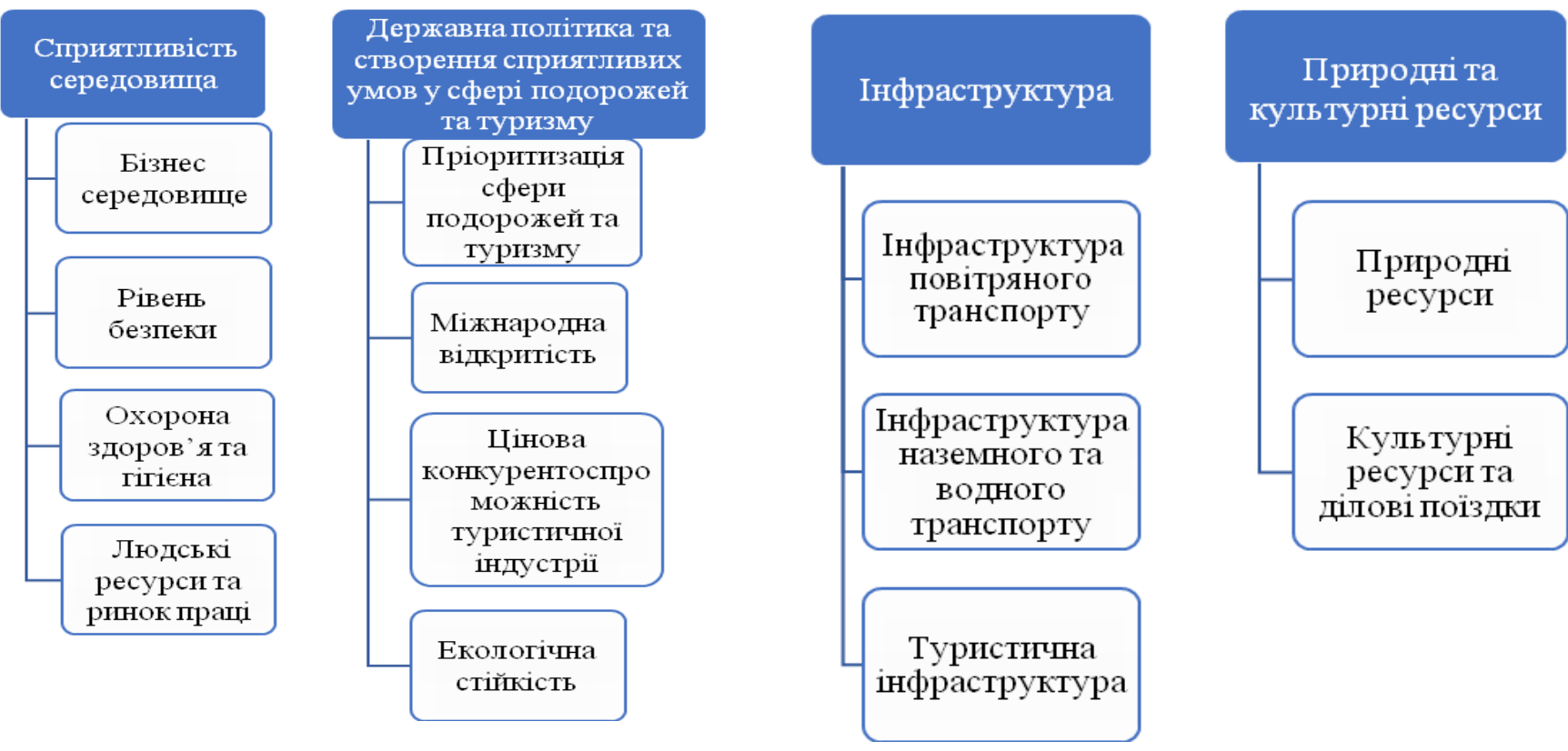

Рис. 2. Складові Індексу конкурентоспроможності

Джерело:складено автором на основі даних $[7,8]$

Відповідно до завдань, завдань дослідження, проаналізуємо дані важливого рейтингу - Індексу конкурентоспроможності країн у сфері подорожей та туризму (The Travel \& Tourism Competitiveness Report, TTCI) [7].

Даний індекс включає в себе сукупність факторів, які впливають на розвиток сфери туризму i подорожей, що сприяє конкурентоспроможності країни. Оцінка індексу конкурентоспроможності 
сфери подорожей татуризму, здійснюється за допомогою певного алгоритму, який складається із 90 чинників. Загальна оцінка формується на основі 14 груп факторів, які згруповані в 4 базових блоки (рис.2).

Україна - не просто одна 3 найкрасивіших країн світу, а одна 3 найдешевших за вартістю проживання для іноземців. Світова туристична організація UNWTO оцінила туристичний потік в Україну у 2019 році в $\$ 1,4$ млрд.

Ключові показники України у 2019:

- Міжнародні туристичні прибуття 14229600.

- Надходження від в 'їзного туризму 1 261,0 млн доларів США.

- Середні надходження на час перебування (прибуття) 526,5 дол США.

- ВВП в сфері Т\& Т (\% від загального1,4\% ) 1794,5 млн. дол США

- Доля промисловості в ВВП \% ВВП 1.4.

- Зайнятість в сфері Т\&Т 206 200роб місць $1.3 \%$ від загального.

- Частка Т\&Т в зайнятості 1,3 \% від загальної зайнятості.

У середині кожної з 14 груп факторів, аналізуються по кілька складових, які допомагають більш детально та об'єктивно зробити оцінку конкурентоспроможності, та визначити перешкоди, які заважають сталому розвитку сфери. У таблиці 1 проаналізовано динаміку зміни показників індексу конкурентоспроможності України у рейтингу 140 країн світу станом на 2013, 2017, 2019 роки.

Динаміка показників індексу конкурентоспроможності за 2013, 2017, 2019 роки [7,8]

\begin{tabular}{|c|c|c|c|c|c|c|}
\hline \multirow{2}{*}{ Показники } & \multicolumn{3}{|c|}{ Місце в рейтингу } & \multicolumn{3}{|c|}{ Середній бал } \\
\hline & 2013 & 2017 & 2019 & 2013 & 2017 & 2019 \\
\hline Загальне місце в рейтингу & 76 & 88 & 78 & 4,0 & 3,5 & 5,0 \\
\hline I. Сприятливість середовища & 60 & 78 & 65 & 4,7 & 4,6 & 5,0 \\
\hline - Бізнес середовище & 71 & 124 & 103 & 3,6 & 3,7 & 4,1 \\
\hline - Рівень безпеки & 77 & 127 & 107 & 4,6 & 3,5 & 4,8 \\
\hline - Охорона здоров’я та гігієна & 8 & 8 & 11 & 6,5 & 6,6 & 6,5 \\
\hline - Людські ресурси та ринок праці & - & 41 & 48 & & 4,9 & 4,8 \\
\hline $\begin{array}{l}\text {-Інфраструктура інформаційно- комунікаційних } \\
\text { технологій }\end{array}$ & 70 & 81 & 78 & 3,1 & 4,2 & 4,5 \\
\hline $\begin{array}{l}\text { II. Державна політика та створення сприятливих умов } \\
\text { у сфері подорожей та туризму }\end{array}$ & 114 & 85 & 70 & 3,9 & 4,1 & 4,5 \\
\hline - Пріоритизація сфери подорожей та туризму & - & 90 & 92 & - & 4,3 & 4,3 \\
\hline - Міжнародна відкритість & - & 78 & 56 & - & 2,9 & 3,7 \\
\hline $\begin{array}{l}\text {-Цінова конкурентоспроможність туристичної } \\
\text { індустрії }\end{array}$ & 110 & 45 & 19 & 4,0 & 5,2 & 5,9 \\
\hline - Екологічна стійкість & 92 & 97 & 114 & 4,3 & 3,9 & 3,9 \\
\hline III. Інфраструктура & 71 & 79 & 73 & 3,6 & 3,1 & 3,4 \\
\hline - Інфраструктура повітряного транспорту & 78 & 791 & 71 & 2,8 & 2,4 & 2,7 \\
\hline - Інфраструктура наземного та водного транспорту & 73 & 81 & 77 & 3,5 & 3,0 & 3,1 \\
\hline - Туристична інфраструктура & 50 & 71 & 65 & 4,6 & 4,0 & 4,3 \\
\hline IV. Природні та культурні ресурси & 99 & 88 & 89 & 3,6 & 2,2 & 2,1 \\
\hline - Природні ресурси & 102 & 115 & 116 & 3,0 & 2,3 & 2,2 \\
\hline - Культурні ресурси та ділові поїздки & 80 & 51 & 55 & 2,1 & 2,1 & 1,9 \\
\hline
\end{tabular}

Згідно показникам даного індексу та проведеного дослідження можна виділити стримуючі фактори у розвитку туризму України, попри загальне зростання у рейтингу: 
- несприятливість середовища (бізнес сфера, рівень безпеки, інфраструктура інформаційнокомунікаційних технологій) - 60 рейтингове місце у 2013 року та 78 місце у 2017 року та 65 у 2019. Набір факторів в межах субіндексу є найбільш стримуючими для галузі, а це набір факторів, які безпосередньо відносяться до компетенцій керівників державного рівня;

- не досконалість державної політики та сприятливих умов у сфері подорожей та туризму (пріоритизація сфери подорожей та туризму, міжнародна відкритість, екологічна стійкість) - 114 рейтингове місце у 2013 року та 85 місце у 2017 року та 70 місце у 2019 році демонструє позитивну динаміку, проте насторожує фактор пониження в рейтингу екологічної стійкості. Це повинно стати ключовим у питаннях державної політик як на макро-, мезо-, та мікрорівнях;

- вкрай низький рівень якості інфраструктури (інфраструктура повітряного транспорту, Інфраструктура наземного та водного транспорту, туристична інфраструктура) - 78 рейтингове місце у 2013 року та 79 місце у 2017 року проти 73 місця у 2091році;

- не належна охорона та відповідальне використання природніх та культурних ресурсів відповідно займає 102 місце рейтингове у 2013 року та 115 місце у 2017 року проти 89 місця у 2019 році.

Про, що можуть свідчити такі показники? Звичайно, Україна має унікальний природньокультурний потенціал, біорізноманіття та культурну спадщину, яка сягає віків. Проте, стримуючим фактором у зацікавленості $\epsilon$ необізнаність туристів через недостатню промоцію туристичних можливостей України.

Таблиия 2

Показники субіндексу «Державна політика та створення сприятливих умов у сфері подорожей в туризмі»

\begin{tabular}{|c|c|c|c|c|c|}
\hline \multirow[b]{2}{*}{ СУБІЕНДЕКС В } & \multicolumn{2}{|l|}{$2017 \mathrm{p}$} & \multicolumn{2}{|l|}{$2019 p$} & \multirow{2}{*}{$\begin{array}{l}\text { Еталонна } \\
\text { країна в } \\
\text { рейтингу за } \\
\text { показником }\end{array}$} \\
\hline & $\begin{array}{l}\text { Місце в } \\
\text { рейтинг } \\
\text { y }\end{array}$ & Бал & $\begin{array}{l}\text { Місце в } \\
\text { рейтингу }\end{array}$ & Бал & \\
\hline $\begin{array}{l}\text { ДЕРЖАВНА ПОЛІТИКА ТА СТВОРЕННЯ } \\
\text { СПРИЯТЛИВИХ УМОВ У СФЕРІ ПОДОРОЖЕЙ В } \\
\text { ТУРИЗМІ }\end{array}$ & 85 & 4,1 & 70 & 4,5 & \\
\hline Пріоритизація розвитку сфери подорожей туризму & 90 & 4,3 & 92 & 4,3 & Мальта \\
\hline $\begin{array}{l}\text { Пріоритетність розвитку сфери туризму для уряду } \\
\text { країни }\end{array}$ & 122 & 3,4 & 124 & 3,5 & Лесото \\
\hline Державні витрати на розвиток туризму (\%) & 36 & 5,1 & 31 & 5,6 & $\begin{array}{l}\text { Сейшельськ } \\
\text { і острови }\end{array}$ \\
\hline $\begin{array}{l}\text { Ефективність маркетингу та рекламних заходів для } \\
\text { залучення туристів }\end{array}$ & 103 & 3,6 & 101 & 3,8 & Лесото \\
\hline $\begin{array}{l}\text { Повнота доступності даних, які щорічно надаються } \\
\text { національними адміністраціями до збірника статистики } \\
\text { туризму Всесвітньої туристичної організації (0-12- } \\
\text { краще) }\end{array}$ & 18 & 92 & 100 & 15 & Іспанія \\
\hline $\begin{array}{l}\text { Своєчасність надання щомісячних щоквартальних } \\
\text { даних до Всесвітньої туристичної організації }(0=21 \\
\text { краще) }\end{array}$ & 104 & 12,0 & 104 & 12 & $*$ \\
\hline Позиція у Рейтингу бренду країни & 65 & 75,2 & 119 & 61,6 & Парагвай \\
\hline Міжнародна відкритість & 78 & 2,9 & 55 & 3,7 & $\begin{array}{l}\text { Нова } \\
\text { Зеландія }\end{array}$ \\
\hline $\begin{array}{l}\text { Візова політика (необхідність віз та складність їх } \\
\text { одержання) (0-100 краще) }\end{array}$ & 105 & 23,0 & 39 & 54,0 & Гаїті \\
\hline $\begin{array}{l}\text { Відкритість країни для створення угод про повітряне } \\
\text { сполучення (0-38 краще) }\end{array}$ & 111 & 7,0 & 113 & 7,0 & $\begin{array}{l}\text { Нова } \\
\text { Зеландія }\end{array}$ \\
\hline Кількість діючих регіональних торговельних угод & 48 & 19,0 & 48 & 22,0 & $*$ \\
\hline $\begin{array}{l}\text { Цінова конкурентоспроможність туристичної } \\
\text { індустрії }\end{array}$ & 45 & 5,2 & 19 & 5,9 & $\begin{array}{l}\text { Іран, } \\
\text { Ісламська } \\
\text { Республіка }\end{array}$ \\
\hline
\end{tabular}




\begin{tabular}{|c|c|c|c|c|c|}
\hline & & & \multicolumn{3}{|c|}{ Продовження таблиці 2} \\
\hline Податки і збори в аеропортах (0-100 краще) & 99 & 61,2 & 60 & 85,3 & $*$ \\
\hline Відносна вартість розміщення в готелі (дол.США) & 29 & 95,4 & 31 & 102,7 & Литва \\
\hline Паритет купівельної спроможності & 2 & 0,3 & 12 & 0,3 & Сгипет \\
\hline Рівень цін на паливо (центів дол.. США за літр) & 65 & 116,0 & 47 & 73,0 & Венесуела \\
\hline Екологічна стійкість & 97 & 3,9 & 114 & 3,9 & Швейцарія \\
\hline Жорність та ступінь регулювання екологічних норм & 110 & 3,3 & 116 & 3,1 & Фінляндія \\
\hline Рівень дотримання екологічних норм законодавства & 116 & 3,0 & 119 & 3,0 & Лесото \\
\hline Сталість розвитку туристичної індустрії & 108 & 3,7 & 100 & 3,9 & Маврикій \\
\hline Концентрація твердих частинок у повітрі (мг/куб.м.) & 90 & 10,4 & 99 & 15,5 & $*$ \\
\hline $\begin{array}{l}\text { Загальна кількість ратифікованих конвенцій по охороні } \\
\text { природи (0-27 краще) }\end{array}$ & 43 & 23 & 95 & 20 & $*$ \\
\hline Прогнозований дефіцит води (5-0 краще) & 89 & 2,9 & 93 & 2,9 & $\begin{array}{l}\text { Люксембур } \\
\text { г }\end{array}$ \\
\hline $\begin{array}{l}\text { Зникаючи види флори і фауни (від загальної кількості } \\
\text { відомих) }\end{array}$ & 78 & 6,4 & 77 & 6,3 & $\begin{array}{l}\text { Сойшелські } \\
\text { острови }\end{array}$ \\
\hline Втрати лісового покриву (\%зміни) & 73 & 0,1 & 75 & 0,1 & $*$ \\
\hline Рівень очистки стічних вод (\%) & 63 & 14,1 & 70 & 14,1 & Йемен \\
\hline $\begin{array}{l}\text { Вплив промислового рибальства на екосистему } \\
\text { морського шельфу (тонн/кВ.кв) }\end{array}$ & 28 & 0,0 & 48 & 30,1 & США \\
\hline
\end{tabular}

Примітка * показник притаманний багатьом країнам

3 огляду на підвищення України в рейтингу на 10 позицій, не можемо залишити поза увагою фактори, які дали цей позитивний результат, а отже вони є сильною стороною галузі. В наступній статті, буде проведено детальний аналіз кожного показника в межа чотирьох субіндексів із визначенням та обгрунтуванням факторів впливу на отримання відповідного балу та займаного місця в рейтингу.

Разом 3 тим, в даному науковому дослідженні звернемо увагу на субіндекс, який, як зазначалось вище, є стримуючим - державна політика та створення сприятливих умов у сфері подорожей в туризмі. Незважаючи на підвищення в рейтингу на 2 сходинки у 2019 році проти 2017 року, ситуація в державотворчому процесі туристичної галузі залишається вкрай не стабільною.

Це пов’язано з постійним реформуванням галузі. Зупинимось на цьому детальніше.

Реалізація пріоритетних напрямків державної політики в галузі туризму, досягнення стратегічних цілей, узгодженість і задоволення інтересів держави та суб'єктів туристичного ринку можливе за рахунок впровадження оптимальної моделі державного регулювання та сприяння розвитку підприємницьких процесів у туристичній галузі можливо за рахунок розбудови відповідної нормативно-правової та інституційної бази.

Нормативно-правове забезпечення розвитку ринку туристичних послуг щільно взаємопов'язано та взаємообумовлене 3 його інституційним базисом. Так, досягнення проголошених цілей та окреслених пріоритетних напрямків розвитку туризму в державі можливо за рахунок системної взаємодії та чіткої регламентації повноважень органів державної влади 3 питань регулювання та управління туристичною галуззю, які утворюють інституційне забезпечення формування та розвитку ринку туристичних послуг.

Проте процес формування «інституційного базису» для українського туризму багато років поспіль перебуває в умовах невизначеності, що ніяк не сприяє цілеспрямованому досягненню цілей «Стратегії розвитку туризму та курортів 2026» прийнятої 2017 року.

Інституційне підгрунтя розвитку туристичного ринку забезпечується Верховною Радою України, Кабінетом Міністрів України, мережею державних органів інституційно-правового управління та регулювання розвитку туризму, Місцевими державними адміністраціями, органами місцевого самоврядування та місцевими органи, що здійснюють регулювання в галузі туризму. Окрему групу утворюють неурядові туристські організації та асоціації універсального та спеціалізованого характеру (рис. 3)

Станом на 2020 рік в інституційному забезпеченні ринку туристичних послуг відбулися деякі зміни: 
- Департамент туризму та курортів, який був у структурі Міністерства економічного розвитку та торгівлі (з 2019 року Міністерство економічного розвитку, торгівлі та сільського господарства) було ліквідовано та утворено Головне управління Директорату туризму в структурі Міністерства (доскладу головного управління туризму Директорату туризму входять два відділи: відділ координації та контролю туристичної діяльності; відділ розвитку туристичних напрямків);

- постановою Кабінету Міністрів України від 24 грудня 2019 р. № 1162 затверджено Положення про Державне агентство розвитку туризму України (Держтуризм) яке $є$ центральним органом виконавчої влади, діяльність якого спрямовується і координується Кабінетом Міністрів України через Міністра культури, молоді та спорту і який реалізує державну політику у сфері туризму та курортів (крім здійснення державного нагляду (контролю) у сфері туризму та курортів).

- Основними завданнями Держтуризму є:

- 1) реалізація державної політики у сфері туризму та курортів (крім здійснення державного нагляду (контролю) у сфері туризму та курортів);

- 2) внесення на розгляд Міністра культури, молоді та спорту пропозицій щодо формування державної політики у сфері туризму та курортів (крім здійснення державного нагляду (контролю) у с сфері туризму та курортів).

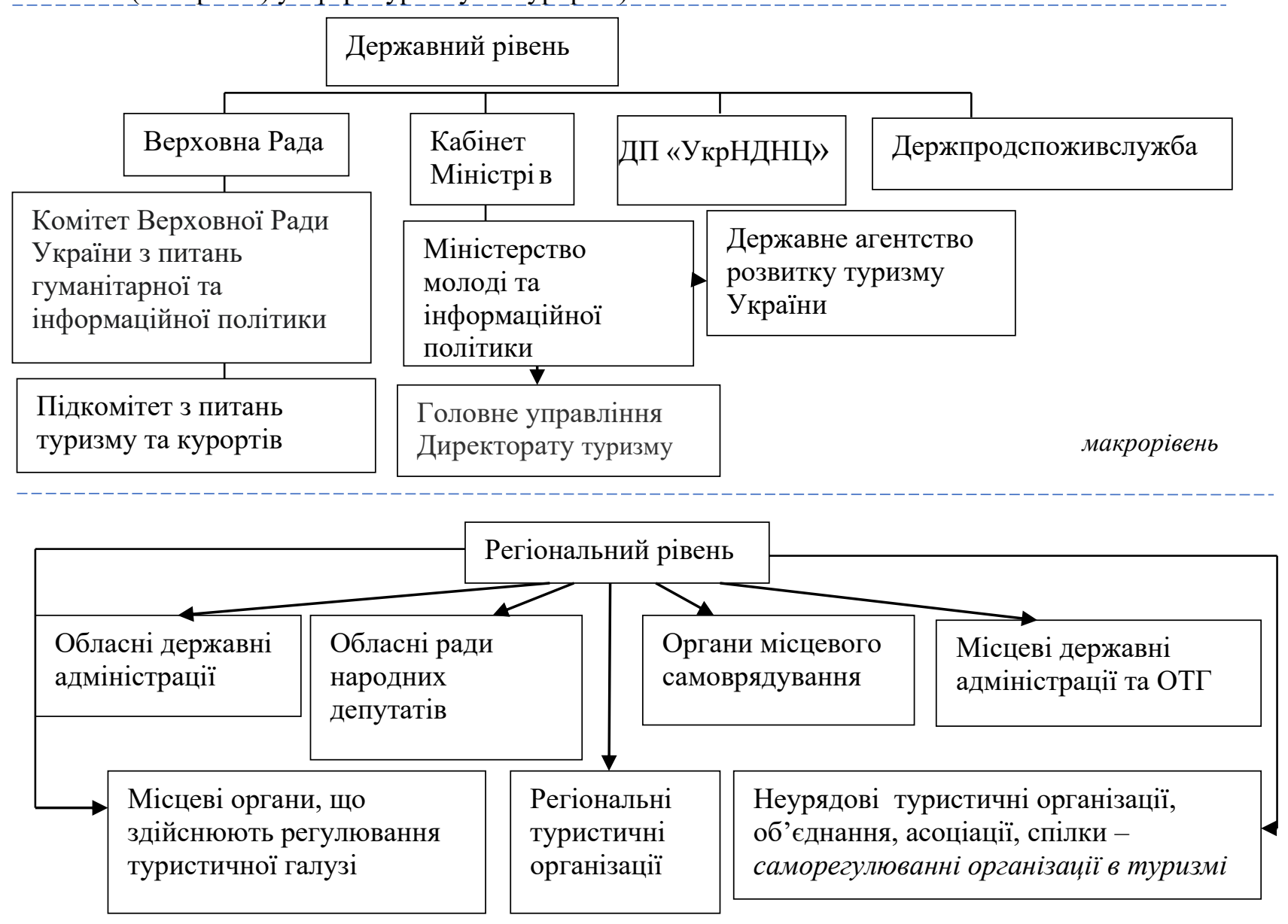

мезорівень

Рис. 3. Інституційне забезпечення ринку туристичних послуг в Украӥні станом на 2020 рік Джерело: власна розробка автора

Висновки і перспективи подальших досліджень. Означені в статті тенденції розвитку туристичного ринку України, складні та суперечливі процеси, які відбуваються, знайшли своє відображення в рейтингу Індексу конкурентоспроможності сфери подорожей та туризму. 
Структури, які забезпечують інституційний розвиток галузі як на мезо-, так і на макро-, рівнях повинні враховувати динаміку показників Індексу спроможності, аналізувати сильні та слабкі фактори в межах кожного субіндексу та брати за основу у прийняті управлінських рішень, програм, стратегій та інше.

Крім цього, задля системного розвитку галузі, вбачаємо за необхідне:

- наділення повноваженнями саморегулівні організації у сфері туризму, які врегульовують діяльність ринку, мають тісний зв'язок на рівні туристичних дестинацій, контролюють якість товарів послуг, формують здорову конкуренцію на ринку;

- створення економічних стимулів для операторів внутрішнього та в'їзного туризму;

- $\quad$ врегулювання питання створення цільового фонду для використання туристичного збору для стимулювання розвитку туристичних дестинацій;

- застосування санкцій до суб'єктів господарювання, які порушують умови діяльності;

- впровадження сучасних інформаційно-комунікаційних технологій на національному та регіональному рівнях;

- розробка та впровадження ефективної комунікаційної стратегії;

- пільгове оподаткування для суб'єктів туристичної діяльності, які забезпечують розвиток внутрішнього туризму;

- організація професійної підготовки та підвищення кваліфікації кадрів;

- стимулювання розвитку інфраструктури туристичних об'єктів через державні програми та проекти;

- врегулювання питання ліцензування, сертифікації діяльності туроператорів, агентів та гідівекскурсоводів;

- $\quad$ оптимізація міжвідомчої комунікації, яка носить хаотичний характер та не узгоджує спільні цілі у розвитку туристичної галузі (зокрема Міністерство Інфраструктури, Мінприроди та інші);

- $\quad$ необхідність розроблення протоколів з дотримання стандартів санітарії та гігієни в сфері туризму;

- розробка окремих державних цільових програм стимулювання здорового екологічного способу життя через стимулювання до активного екологічного туризму, що в підсумку сприятиме відродженню галузі після кризи;

- врегулювати діяльність індивідуальних засобів розміщення (сільський туризм), яка передбачає: обов'язкову реєстрацію суб'єкта господарювання та встановити норму садиби до 8 -15 осіб за межами села; обов'язкова реєстрація в межах села 10-30 осіб із пільговою системою оподаткування.

Зазначені пропозиції сприятимуть покращенню низки факторів, що відображено в показниках Індексу конкурентоспроможності та сприятимуть розвитку активного екологічного туризму в Україні та сталому розвитку сільських територій через стимулювання самозайнятості населення, надходження податків до місцевих бюджетів та покращення туристичної інфраструктури.

\section{Джерела та література}

1. Трегубов О. С. Особливості конкуренції в туризмі Економіка і організаџія управління. 2016. № 2 (22) . C.101-107.

2. Національна туристична організація України. [Електронний ресурс]. - Режим доступу: http://www.ntoukraine.org/ntoukriane_2020_ua.html

3. Явкін В. Г., Руденко В. П., Король О. Д. Проблеми географії та менеджмент туризму : Монографія. Чернівці : Рута, 2006. 260 c.

4. Економічна статистика. Економічна діяльність. Туризм. [Електронний ресурс]. - Режим доступу: http://www.ukrstat.gov.ua/operativ/menu/menu_u/tur.htm

5. Державна прикордонна служба України. [Електронний ресурс]. - Режим доступу: https://dpsu.gov.ua

6. Міжнародні рейтинги України. Вікіпедія : [Електронний ресурс]. - Режим доступу: https://uk.wikipedia. org/wiki/Мiжнародні_рейтинги_України.

7. The Travel \& Tourism Competitiveness Report 2019. [Електронний ресурс]. - Режим доступу: https://www.weforum.org/reports/the-travel-tourism-competitiveness-report-2019

8. The Travel \& Tourism Competitiveness Report 2017. [Електронний ресурс]. - Режим доступу: https://www.weforum.org/reports/the-travel-tourism-competitiveness-report-2017 


\section{References}

1. Treghubov O. S. (2016) Osoblyvosti konkurenciji v turyzmi [The peculiarities of competition in tourism]. Ekonomika i orghanizacija upravlinnja - The economics and management, 2,101-107 [in Ukrainian].

2. Natsional'na turystychna orhanizatsiya Ukrayiny [National Tourism Organization of Ukraine]: Website (2020). - Retrieved from http://www.ntoukraine.org [in Ukrainian].

3. Iavkin V. H., Rudenko V. P., Korol O. D., (2016) Problemy heohrafii ta menedzhment turyzmu [Problems of geography and management of tourism] - Chernivtsi: Ruta, 2006. - 260 s. [in Ukrainian].

4. Ekonomichna statystyka. Ekonomichna diyal’nist`. Tury`zm. [Economic statistics. Economic activity. Tourism] - Retrieved from http://www.ukrstat.gov.ua/operativ/menu/menu_u/tur.htm [in Ukrainian].

5. Derzhavna prykordonna sluzhba Ukrayiny. [State Border Guard Service of Ukraine] - Retrieved from https://dpsu.gov.ua [in Ukrainian].

6. Mizhnarodni rejtyngy Ukrayiny. Vikipediya [International ratings of Ukraine. Wikipedia] - Retrieved from https://uk.wikipedia.org/wiki/Мiжнародні_рейтинги_України. [in Ukrainian].

7. The Travel \& Tourism Competitiveness Report 2019. - Retrieved from: https://www.weforum.org/reports/the-travel-tourism-competitiveness-report-2019

8. The Travel \& Tourism Competitiveness Report 2017. - Retrieved from https://www.weforum.org/reports/thetravel-tourism-competitiveness-report-2017

Стаття надійшла до редакції 13.05.2020 р. 